\title{
The N-shaped orthotopic ileal neobladder: functional outcomes and complication rates in 119 patients
}

Thomas De Sutter ${ }^{1}$, Murat Akand ${ }^{1,2}$, Maarten Albersen ${ }^{1}$, Wouter Everaerts ${ }^{1}$, Ben Van Cleynenbreugel ${ }^{1}$, Dirk De Ridder ${ }^{1}$, Hans Goethuys ${ }^{3}$, Lisa Moris ${ }^{1}$, Uros Milenkovic ${ }^{1}$, Hendrik Van Poppel ${ }^{1}$, Frank Van Der Aa ${ }^{1}$ and Steven Joniau ${ }^{1 *}$

\begin{abstract}
Background: We report our long-term experience with 119 cases of $\mathrm{N}$-shaped orthotopic ileal neobladder. Methods: Between March 1996 and July 2013, a total of 119 patients (102 men, 17 women) underwent cystectomy with creation of an $\mathrm{N}$-shaped orthotopic ileal neobladder. The Clavien-Dindo classification score was used for grading early ( $<3$ months postoperative), late, and pouch-related and non-pouch-related complications. Daytime and nighttime continence were evaluated for male and female patients separately, with patients subdivided in three groups: completely continent, use of $\leq 1$ pad, and use of $>1$ pad.

Results: Median follow-up was 75 months (range 3-204). Early complications (15 major, 54 minor) occurred in $39.5 \%$ of 119 patients whereas $53.1 \%$ presented with late complications (56 major, 39 minor; 111 patients evaluated). Urinary infection and outlet obstruction were both the most frequent early and late pouch-related complications; early non-pouch-related complications were mainly infectious and gastrointestinal, and the most common late non-pouch-related problem was wound herniation. At 12 months, 96 and $60 \%$ of the men and 84.6 and $66.7 \%$ of the women respectively achieved daytime and nighttime continence.

Conclusion: Complication rates of the N-shaped orthotopic ileal neobladder were relatively high, probably because of meticulous recording and follow-up. Daytime continence rates were better than nighttime rates. N-shaped orthotopic ileal neobladder can be a good option for urinary diversion in selected patients who undergo radical cystectomy.
\end{abstract}

Keywords: Cystectomy, lleal orthotopic neobladder, Bladder substitution, Complications, Continence

\section{Background}

Radical cystectomy (RC) with pelvic lymph node dissection and urinary diversion is the standard therapy for non-metastatic muscle-invasive bladder cancer and high-risk non-muscle-invasive bladder cancer (Witjes et al. 2014). Over the last two decades, orthotopic ileal neobladder (OIN) has gained popularity, with the Hautmann and Studer pouches used commonly (Hautmann

\footnotetext{
*Correspondence: steven.joniau@uzleuven.be

1 Department of Urology, University Hospitals Leuven, Herestraat 49, 3000 Leuven, Belgium

Full list of author information is available at the end of the article
}

2003; Hautmann et al. 2013). Compared to the ileal conduit (IC), it offers similar cancer control rates and possibly a higher quality of life by preserving continence and near-normal voiding function, avoiding urinary stoma (Yossepowitch et al. 2003; Hautmann et al. 2006; Studer et al. 2006). Disadvantages are the more complex surgical procedure, higher risk of postoperative complications, and a significant risk of (nighttime) incontinence or even hypercontinence, the latter especially in women (Hautmann et al. 1999; Arai et al. 1999). The importance of intensive pelvic floor re-education to reduce incontinence rates has been acknowledged (Arai et al. 1999). Orthotopic bladder substitution (OBS) is therefore 
indicated only for highly motivated and cognitively capable patients. In neobladder creation, different parts of the gastrointestinal tract have been variously suggested for use (Hinman 1998). At present, a detubularized segment of ileum is recommended (Hautmann 2003; Hautmann et al. 2013), offering a low-pressure reservoir with good capacity (Hautmann et al. 2013; Nam et al. 2013; Singh et al. 2014).

In 2005, we published our early results in 58 patients undergoing $\mathrm{RC}$ and OBS with the N-shaped ileal neobladder, with a mean follow-up of 38 months (Joniau et al. 2005). We now report a series of 119 consecutive patients and describe long-term experience with the Leuven $\mathrm{N}$-pouch technique, creating an ileal pouch with an isoperistaltic afferent limb onto which both ureters are anastomosed in an end-to-end fashion. This technique combines features of the popular Hautmann and Studer neobladders, creating a good-capacity pouch with an active anti-reflux mechanism (Hautmann et al. 1988; Studer et al. 1989). The aim of this retrospective study was primarily to assess our longterm experience in terms of complication rates and continence.

\section{Methods}

\section{Patient population and study design}

Between March 1996 and July 2013, a total of 810 RCs were performed at our tertiary referral institution (UZ Leuven, Belgium), and 119 consecutive patients (102 men and 17 women) underwent cystectomy with $\mathrm{N}$-shaped OIN reconstruction. We reviewed their medical records retrospectively in accordance with the ethical standards laid down in the 1964 Declaration of Helsinki and its later amendments. The confidentiality of patient data was guaranteed.

Absolute contraindications were prostatic stromal tumor invasion, inflammatory bowel disease, and impaired renal function (serum creatinine $>2.0 \mathrm{mg} / \mathrm{dL}$ ) and liver function. Other (relative) exclusion criteria were poor physical condition, salvage cystectomy, extensive local tumor burden, cognitive incapability, and lack of motivation or physical inability to perform intermittent catheterization.

\section{Follow-up}

Database collection was based on outpatient and admission reports until June 2015. Standard outpatient visits took place at 3-month intervals during the first two postoperative years, at 6-month intervals up to the fifth year, and yearly thereafter. Physical examination was performed at every visit, as were laboratory tests (blood count, renal and liver function, sodium, potassium, chloride, bicarbonate, and vitamin B12 from the third year on) and imaging. Abdominal ultrasound and chest X-ray were alternated with abdominal and thoracic computed tomography scans.

\section{Surgical technique}

Cystoprostatectomy was performed in men while women underwent cystectomy with sparing of the urethropelvic ligament and the neurovascular structures of the urethra. Of the 17 women, 9 had anterior exenteration while 8 had cystectomy alone. A bilateral pelvic lymph node dissection was performed for any patient with an indication of oncological disease.

Subsequently, an $\mathrm{N}$-shaped neobladder was created with a $50-\mathrm{cm}$ segment of preterminal ileum. This segment was folded into four equally long parts, three of them forming the $\mathrm{N}$-shaped pouch while the most proximal part remained intact, forming the afferent isoperistaltic limb onto which the ureters were anastomosed in an end-to-end fashion separately (Fig. 1). An exact description of this technique has been published previously (Joniau et al. 2005).

\section{Complications}

Complications were registered as early (occurring within 3 months postoperative) or late, as well as pouch-related or non-pouch-related. The validated Clavien-Dindo classification score (CCS) was used to grade complications (Dindo et al. 2004). CCS I and II were considered to indicate minor complications and CCS III to V major complications. In addition, the treatment for these complications was noted, in particular conservative, endoscopic, or open surgical therapy.

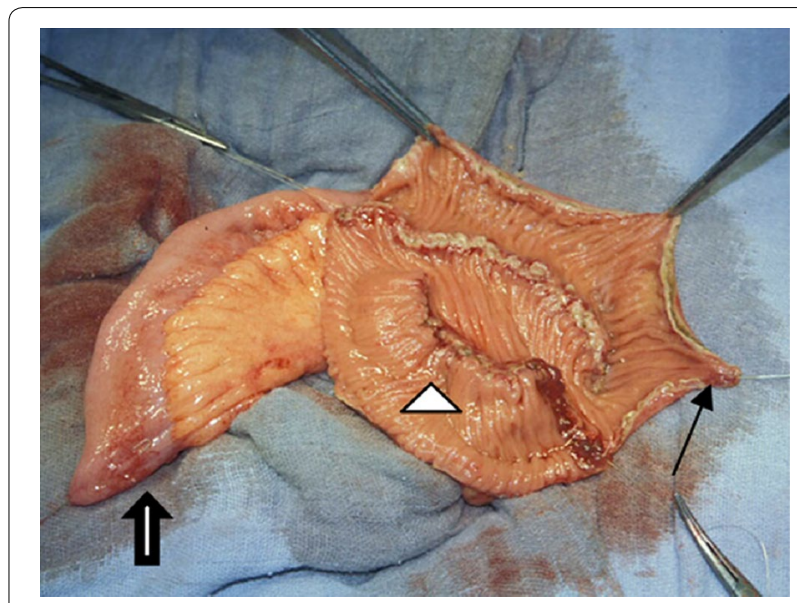

Fig. 1 The N-shaped orthotopic ileal neobladder. Large arrow Intact afferent isoperistaltic segment, acting as an active anti-reflux mechanism. The ureters are anastomosed to this segment in an end-to-end manner. Arrowhead Three antimesenterically opened ileal segments, creating the N-shaped pouch. Small arrow The lowest point of the pouch, forming the urethral anastomosis 


\section{Continence}

Continence was assessed during follow-up visits. For subdividing the patients according to their continence status, we used the UCLA-Prostate Cancer Index with a minor modification (Litwin et al. 1998). In this way, continence was defined with more strict criteria, and patients were divided into three groups: Group 1 (G1), patients without any need for protection; Group 2 (G2), those in need of maximally one (safety) pad; and Group 3 (G3), those using more than one pad, a diaper, or a condom catheter. Daytime continence (DTC) and nighttime continence (NTC) were evaluated separately.

\section{Voiding pattern and catheterization}

Micturition was evaluated primarily at consultation visits, where information about urinary loss, catheterization need and spontaneous voiding was acquired. Clean intermittent self-catheterization was started for those with a post-micturitional residue of more than $150 \mathrm{~mL}$ or recurrent urinary tract infections (UTIs).

\section{Statistical analysis}

Descriptive analyses were performed with SPSS version 15.0 (SPSS Inc., Chicago, Illinois, USA), and were given as median and range for continuous quantitative variables and as percentages for non-numeric variables.

\section{Results}

\section{Population}

The median age of the men was 59 years (range 34-74); for women, it was 55 years (range 29-68). Median followup was 75 months (range 3-204 months).

Elective OBS was performed in 118 patients; one patient undergoing bilateral distal ureterectomy suffered a rupture of a very fibrotic bladder wall, and subsequent cystectomy with ileal neobladder reconstruction was performed. Bladder transitional cell carcinoma was the operative indication in the vast majority of patients (95.7\%). Only 30 patients (25.2\%) (25 men and 5 women) had a nerve-sparing surgery (23 bilateral, 7 unilateral).

Five patients presented preoperatively with positive lymph nodes, four of whom were treated with neo-adjuvant chemotherapy. Another 14 patients with muscle-invasive bladder cancer received neo-adjuvant chemotherapy. Patient demographics and disease characteristics are described in Table 1. Because of cancerrelated and other cause deaths, the short- and long-term follow-up data differ.

\section{Complication rates}

Of the 119 patients, 47 (39.5\%) had early complications ( $\leq 3$ months), and 59 of 111 evaluable patients (53.1\%) had late complications ( $>3$ months). One patient died in
Table 1 Patient demographics, disease characteristics, procedural data, and pre- and postoperative pathology results

\begin{tabular}{|c|c|c|c|}
\hline \multicolumn{3}{|c|}{ Number of patients (Male/Female) } & $119(102 / 17)$ \\
\hline \multicolumn{3}{|c|}{ Age (years) } & $\begin{array}{l}\text { Male: } 59 \text { (34-74) } \\
\text { Female: } 55 \text { (29-68) }\end{array}$ \\
\hline \multicolumn{3}{|c|}{ Follow up (months) } & $75(3-204)$ \\
\hline \multicolumn{4}{|c|}{ Operative indication } \\
\hline \multicolumn{3}{|c|}{ Transitional cell carcinoma } & 113 pts \\
\hline \multicolumn{3}{|c|}{ Interstitial cystitis } & 2 pts \\
\hline \multicolumn{3}{|c|}{ Vesicorectal fistula } & $1 \mathrm{pt}$ \\
\hline \multicolumn{3}{|c|}{ Prostate cystadenoma } & $1 \mathrm{pt}$ \\
\hline \multicolumn{3}{|c|}{ Persistant leakage from continent vesicostomy } & $1 \mathrm{pt}$ \\
\hline \multicolumn{3}{|c|}{ Bladder wall calcification after BCG } & $1 \mathrm{pt}$ \\
\hline \multicolumn{3}{|c|}{ Operation time (min) } & $210(120-360)$ \\
\hline \multicolumn{3}{|c|}{ Blood loss (mL) } & $1100(100-3600)$ \\
\hline T stage & Preoperative & Postoperative & Positive LN \\
\hline T0 & $3(2.7 \%)$ & $29(25.7 \%)$ & $1 / 29(3.4 \%)$ \\
\hline Tx & $3(2.7 \%)$ & $0(0 \%)$ & $0(0 \%)$ \\
\hline Tis & $5(4.4 \%)$ & $9(7.9 \%)$ & 0/9 (0 \%) \\
\hline Ta & $1(0.8 \%)$ & $5(4.4 \%)$ & 0/5 (0 \%) \\
\hline T1 & $22(19.5 \%)$ & $15(13.3 \%)$ & $1 / 15(6.7 \%)$ \\
\hline $\mathrm{T} 2$ & $75(66.4 \%)$ & $22(19.5 \%)$ & 4/22 (18.2\%) \\
\hline T3 & 4 (3.5 \%) & $29(25.7 \%)$ & $12 / 29(41.4 \%)$ \\
\hline T4 & $0(0 \%)$ & $4(3.5 \%)$ & $3 / 4$ (75 \%) \\
\hline Total & $113(100 \%)$ & $113(100 \%)$ & $21 / 113(18.6 \%)$ \\
\hline
\end{tabular}

Data are given as either median (range) or $n$ (\%)

the perioperative period due to perforation of the small intestine, which resulted in septic shock and acute myocardial infarction. Seven other patients had no long-term follow-up ( $>3$ months) because of death within the first year (>3 months) (5 patients; 4 cancer-related and 1 death at home for unknown reasons), follow-up abroad (1 patient), or loss to follow-up (1 patient). All complications were counted separately, and some patients experienced more than one complication.

\section{Early complications}

Table 2 gives an overview of the early complications and their management. In 119 patients, we registered 15 major early complications (CCS III-V) compared to 54 minor early complications (CCS I-II). Early pouchrelated complications occurred in 23 patients (19.3\%). UTI was the most frequent, occurring in 17 patients (14.3\%), with 14 cases classified as minor and 3 that led to urosepsis with intensive care admission. Non-pouchrelated early complications occurred in 33 patients (27.7 \%). Minor complications were diverse and almost equally distributed among gastrointestinal (8.4\%), pulmonary (6.7 \%), and wound-related problems (5\%). Six 
Table 2 Overview of early complications ( $\leq 3$ months) (pouch and non-pouch-related) by the Clavien-Dindo classification in 119 patients

\begin{tabular}{ll}
\hline Clavien-Dindo score (CCS) & Number of complications (\%) \\
\hline Major & $1(0.8 \%)$ \\
V & \\
a & $0(0 \%)$ \\
b & $3(2.5 \%)$ \\
III & \\
a & $3(2.5 \%)$ \\
b & $8(6.7 \%)$ \\
Minor & \\
II & $34(28.6 \%)$ \\
I & $20(16.8 \%)$ \\
\hline Complication & N (\%) \\
\hline
\end{tabular}

Early pouch-related complications

Major

\begin{tabular}{|c|c|c|c|}
\hline Urosepsis & $3(2.5 \%)$ & $\mathrm{IVb}$ & Intensive care \\
\hline $\begin{array}{l}\text { Ureteroneovesical } \\
\text { stenosis }\end{array}$ & $2(1.7 \%)$ & $\| l \mid b$ & $\begin{array}{l}\text { Re-implantation }(1 \times) \\
\text { Transureteroureterostomy } \\
(1 \times)\end{array}$ \\
\hline $\begin{array}{l}\text { Enteroneovesical } \\
\text { fistula }\end{array}$ & $1(0.8 \%)$ & $111 \mathrm{~b}$ & Open surgery \\
\hline $\begin{array}{l}\text { Neovesicocutaneus } \\
\text { fistula }\end{array}$ & $1(0.8 \%)$ & IIlb & Endoscopic examination \\
\hline Neobladder bleeding & $1(0.8 \%)$ & 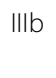 & $\begin{array}{l}\text { Endoscopic examina- } \\
\text { tion + Rinsing }\end{array}$ \\
\hline Mucus retention & $1(0.8 \%)$ & IIla & $\begin{array}{l}\text { Endoscopic examina- } \\
\text { tion + Rising }\end{array}$ \\
\hline \multicolumn{4}{|l|}{ Minor } \\
\hline $\begin{array}{l}\text { Urinary tract infec- } \\
\text { tion (pyelonephritis, } \\
\text { pouchitis, fever after } \\
\text { removal of single-J } \\
\text { stents) }\end{array}$ & $14(11.8 \%)$ & $\|$ & Antibiotics \\
\hline Clot retention & $1(0.8 \%)$ & $\|$ & Rinsing + Antibiotics \\
\hline Mucus retention & $2(1.7 \%)$ & । & Rinsing \\
\hline Urinoma & $1(0.8 \%)$ & । & Prolonged drainage \\
\hline \multicolumn{4}{|c|}{ Early non-pouch-related complications } \\
\hline \multicolumn{4}{|l|}{ Major } \\
\hline $\begin{array}{l}\text { Death (small bowel } \\
\text { perforation resulting } \\
\text { in septic shock and } \\
\text { myocardial infarction) }\end{array}$ & $1(0.8 \%)$ & V & $\begin{array}{l}\text { Open surgery (laparot- } \\
\text { omy) + Intensive care }\end{array}$ \\
\hline Mesenterial bleeding & $1(0.8 \%)$ & IIlb & Open surgery \\
\hline Evisceration & $1(0.8 \%)$ & $\| l l b$ & Open surgery \\
\hline Textilloma & $1(0.8 \%)$ & IIIb & Open surgery \\
\hline Peptic ulcer & $1(0.8 \%)$ & Illa & Gastroscopy \\
\hline Pneumothorax & $1(0.8 \%)$ & IIla & Chest drain \\
\hline \multicolumn{4}{|l|}{ Minor } \\
\hline Pneumonia & $5(4.2 \%)$ & ॥ & Antibiotics \\
\hline Catheter sepsis & $4(3.4 \%)$ & ॥ & Antibiotics \\
\hline
\end{tabular}

Table 2 continued

\begin{tabular}{|c|c|c|c|}
\hline Complication & $\mathrm{N}(\%)$ & CCS & Treatment \\
\hline Lung embolism & $3(2.5 \%)$ & $\|$ & $\begin{array}{l}\text { Low molecular weight } \\
\text { heparin }\end{array}$ \\
\hline Ileus & $2(1.7 \%)$ & $\|$ & $\begin{array}{l}\text { Total parenteral nutrition } \\
(1 \times) \\
\text { Jejunal catheter }(1 \times)\end{array}$ \\
\hline Fever (unknown origin) & $1(0.8 \%)$ & $\|$ & Antibiotics \\
\hline Back pain & $1(0.8 \%)$ & ॥ & Epidural infiltration \\
\hline Acidosis & $1(0.8 \%)$ & $\|$ & Intravenous bicarbonate \\
\hline $\begin{array}{l}\text { Deep venous throm- } \\
\text { bosis }\end{array}$ & $1(0.8 \%)$ & $\|$ & $\begin{array}{l}\text { Low molecular weight } \\
\text { heparin }\end{array}$ \\
\hline Wound abscess & $1(0.8 \%)$ & $\|$ & Drainage + Antibiotics \\
\hline $\begin{array}{l}\text { Wound problems } \\
\text { (dehiscence, fat } \\
\text { necrosis) }\end{array}$ & $5(4.2 \%)$ & । & Vacuum therapy \\
\hline Ileus & $5(4.2 \%)$ & । & Conservative \\
\hline Delirium & $3(2.5 \%)$ & । & Oral medication \\
\hline Diarrhea & $3(2.5 \%)$ & । & Conservative \\
\hline Catheter sepsis & $1(0.8 \%)$ & । & $\begin{array}{l}\text { Removal of deep venous } \\
\text { catheter }\end{array}$ \\
\hline
\end{tabular}

patients (5\%) presented with major complications, and open surgical exploration was necessary in four of them because of small bowel perforation, mesenterial bleeding, evisceration and removal of a textiloma.

\section{Late complications}

Table 3 gives an overview of all late complications and their management. We registered 56 major complications (CCS III-V) in 111 patients and 39 minor complications (CCS I-II). Late pouch-related complications were detected in 47 of 111 patients (42.3\%), most of which were infectious or obstructive (neovesicourethral or ureteroneovesical). Urosepsis was diagnosed in 3 patients $(2.7 \%)$ and relapsing UTIs or pyelonephritis in 26 (23.4\%). Neovesicourethral stenosis (NUS) was noted in $9.9 \%(\mathrm{n}=11)$, acute urinary retention due to mucus clot in $5.4 \%(\mathrm{n}=6)$, and ureteroneovesical stenosis in $5.4 \%$ $(\mathrm{n}=6)$. In two patients, a renal unit was lost because of long-term ureteroneovesical obstruction.

Late non-pouch-related complications were registered in 22 patients $(19.8 \%)$. Herniation of the laparotomy scar was surgically corrected with a mesh in 17 patients.

\section{Pouch survival}

Four patients had their N-pouch removed. Urethral tumor recurrence was noted in two patients in whom salvage urethropouchectomy and construction of an IC was performed. The other indications were neobladder hyper-contractility and neobladder-rectal fistula in a 
Table 3 Overview of late complications (>3 months) (pouch and non-pouch-related) by the Clavien-Dindo classification in 111 patients

\begin{tabular}{ll}
\hline Clavien-Dindo score (CCS) & Number of complications (\%) \\
\hline Major & $1(0.9 \%)$ \\
V & \\
IV & $4(3.6 \%)$ \\
a & $0(0 \%)$ \\
b & \\
III & $2(1.8 \%)$ \\
a & $49(44.1 \%)$ \\
b & \\
Minor & $28(25.2 \%)$ \\
II & $11(9.9 \%)$ \\
I & CCS Treatment \\
\hline Complication & N (\%)
\end{tabular}

Late pouch-related complications

Major

\begin{tabular}{|c|c|c|c|}
\hline $\begin{array}{l}\text { Death (abscess forma- } \\
\text { tion in base of penis } \\
\text { after false-passage } \\
\text { catheterization, } \\
\text { resulting in sep- } \\
\text { sis + multiple organ } \\
\text { failure) }\end{array}$ & 1 (0.9\%) & V & $\begin{array}{l}\text { Debridement + Intensive } \\
\text { care }\end{array}$ \\
\hline Loss of renal unit & $2(1.8 \%)$ & IVa & Conservative \\
\hline $\begin{array}{l}\text { Ischemic perforation of } \\
\text { neobladder }\end{array}$ & $1(0.9 \%)$ & IVa & $\begin{array}{l}\text { Laparotomy + Intensive } \\
\text { care }\end{array}$ \\
\hline Urosepsis & $1(0.9 \%)$ & IVa & $\begin{array}{l}\text { Intensive care + Conserva- } \\
\text { tive therapy }\end{array}$ \\
\hline Pouch calculi & $8(7.2 \%)$ & $111 \mathrm{~b}$ & Laser lithotripsy \\
\hline $\begin{array}{l}\text { Neovesicourethral } \\
\text { stenosis }\end{array}$ & $11(9.9 \%)$ & $\| l l b$ & $\begin{array}{l}\text { Internal optical urethrot- } \\
\text { omy }(4 \times) \\
\text { Transurethral resection } \\
\quad(5 x) \\
\text { Dilatation under general } \\
\text { anesthesia }(2 x)\end{array}$ \\
\hline $\begin{array}{l}\text { Ureteroneovesical } \\
\text { stenosis }\end{array}$ & $6(5.4 \%)$ & IIIb & $\begin{array}{l}\text { Ureteral reimplantation } \\
\quad(4 \times) \\
\text { Lifelong single-J stenting } \\
\quad(2 \times)\end{array}$ \\
\hline Stress incontinence & $2(1.8 \%)$ & $\| l l b$ & $\begin{array}{l}\text { Single incision mid-ure- } \\
\text { thral sling }(1 \times) \\
\text { Fascia lata sling }(1 \times)\end{array}$ \\
\hline Mucus obstruction & $1(0.9 \%)$ & $111 \mathrm{~b}$ & Endoscopic evaluation \\
\hline $\begin{array}{l}\text { Neovesicocutaneous } \\
\text { fistula }\end{array}$ & $1(0.9 \%)$ & IIIb & Open excision \\
\hline Neovesicorectal fistula & $1(0.9 \%)$ & IIIb & $\begin{array}{l}\text { Laparotomy }+ \text { Conversion } \\
\text { to ileal conduit }\end{array}$ \\
\hline $\begin{array}{l}\text { Hypercontractile neo- } \\
\text { bladder with severe } \\
\text { incontinence }\end{array}$ & $1(0.9 \%)$ & $\| l l b$ & $\begin{array}{l}\text { Laparotomy + Conversion } \\
\text { to ileal conduit }\end{array}$ \\
\hline Ureterolithiasis & $1(0.9 \%)$ & Illa & Nephrostomy \\
\hline $\begin{array}{l}\text { False-passage catheteri- } \\
\text { zation }\end{array}$ & $1(0.9 \%)$ & Illa & Endoscopic evaluation \\
\hline
\end{tabular}

Table 3 continued

\begin{tabular}{|c|c|c|c|}
\hline Complication & N (\%) & CCS & Treatment \\
\hline \multicolumn{4}{|l|}{ Minor } \\
\hline $\begin{array}{l}\text { Relapsing urinary tract } \\
\text { infections and pyelone- } \\
\text { phritis }\end{array}$ & $26(23.4 \%)$ & $\|$ & Antibiotics \\
\hline Urosepsis & $2(1.8 \%)$ & $\|$ & $\begin{array}{l}\text { Antibiotics + Fluid resus- } \\
\text { citation }\end{array}$ \\
\hline Mucus obstruction & $5(4.5 \%)$ & 1 & Conservative \\
\hline \multicolumn{4}{|c|}{ Late non-pouch-related complications } \\
\hline \multicolumn{4}{|c|}{ Major } \\
\hline Wound herniation & $17(15.3 \%)$ & $\| l \mathrm{~b}$ & Open repair \\
\hline Small bowel obstruction & $1(0.9 \%)$ & $\| l \mathrm{~b}$ & Open adhesiolysis \\
\hline \multicolumn{4}{|l|}{ Minor } \\
\hline Diarrhea & $6(5.4 \%)$ & 1 & Conservative \\
\hline
\end{tabular}

patient who underwent previous radiotherapy for prostate cancer.

Urethral tumor recurrence was also diagnosed in another two patients, who had endoscopic resection of the lesions. All four patients with urethral tumor recurrence remained alive until last follow-up.

\section{Continence rates}

Among the male patients, for DTC at the 3-month interval, $41.5 \%$ of 94 patients were in G1, $40.5 \%$ in G2, and $18 \%$ in G3. At last follow-up, these rates were 83.1, 11.3, and $5.6 \%$, respectively, in 71 patients (Fig. 2a). For NTC at the 3-month interval, 11.2, 21.3, and $67.5 \%$ of 89 male patients were in G1, G2, and G3, respectively. Of 71 patients evaluated at last follow-up, these values were respectively 38 , 25.4 , and $36.6 \%$. Of 26 incontinent patients (G3), 20 used diapers or condom catheters (Fig. 2b).

Among the women, for DTC at the 3-month interval, $31.25,31.25$, and $37.5 \%$ of 16 patients were in G1, G2, and G3, respectively; these percentages were $45.5,36.3$, and $18.2 \%$ of 11 patients at last follow-up. Of note, the two incontinent patients at last follow-up eventually underwent a sling procedure for deteriorating stress incontinence (Fig. 3a). Regarding NTC at the 3-month interval, 26.6, 26.6, and $46.8 \%$ of 15 women were respectively in G1, G2, and G3, whereas these rates were 41.6, 8.4 , and $50 \%$, respectively, for 12 patients at last followup. Five out of six women in G3 used diapers (Fig. 3b).

\section{Hypercontinence and catheterization}

Clean intermittent self-catheterization was necessary in 8 out of 17 female patients ( $47 \%$ ), and none of them could void spontaneously. With the exclusion of six patients because of death or loss to follow-up, 18 out of $99(18 \%)$ 


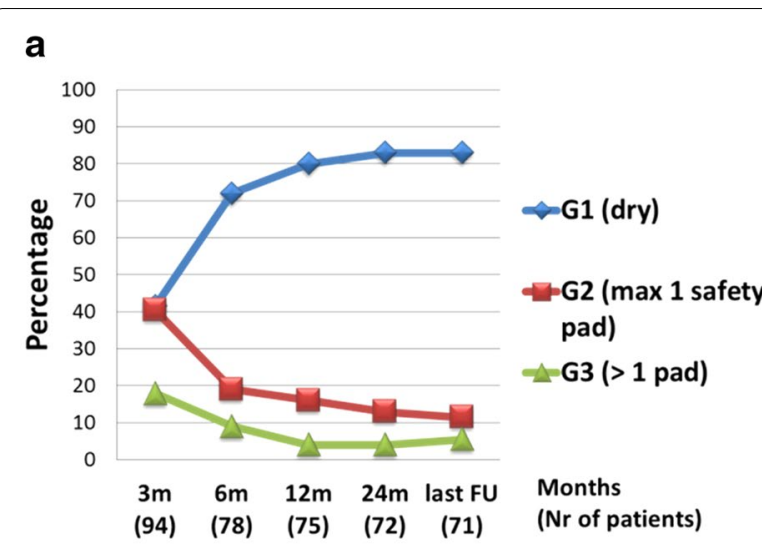

b

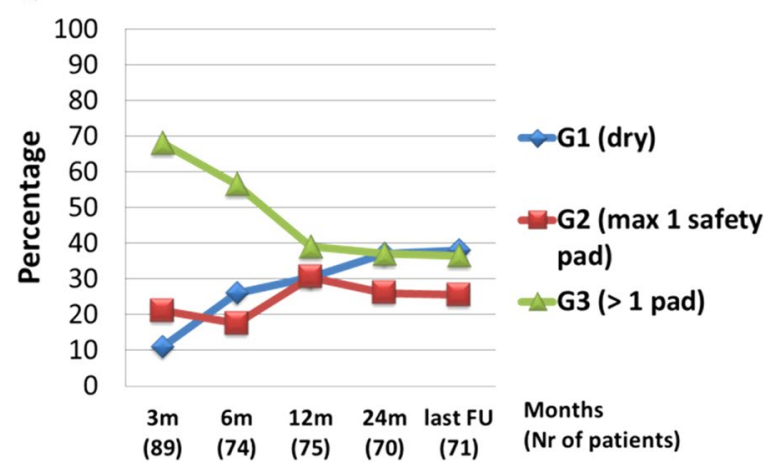

Fig. 2 Male continence. a Daytime male continence. b Nighttime male continence

male patients required catheterization of whom 12 could still void spontaneously. Of these hypercontinent men, 5 (28\%) had NUS, 2 (11\%) had mucus retention while 11 (61 \%) had no clear reason. In the female hypercontinent population, no NUS was observed.

\section{Discussion}

Urinary diversion after $\mathrm{RC}$ can be performed in various ways. For OIN, numerous techniques with different intestinal segments and configurations have been described. The 2014 update of the European Association of Urology guidelines in muscle-invasive and metastatic bladder cancer recommends performing an OBS for both male and female patients who do not have any contraindication or tumor in the urethra (grade B recommendation) (Witjes et al. 2014). Nevertheless, population-based studies from Sweden and the United States indicate that OBS is being performed much less frequently than IC, with a rate of approximately $15 \%$ (Jahnson et al. 2008; Gore et al. 2009). OBS is generally preserved for highly motivated and cognitively capable patients. In a 17-year period, we performed 119 (14.7\% of total) consecutive cystectomies with OBS; in the same time span, 691 patients underwent IC in our institution. These relative numbers emphasize our thorough healthier and younger patient selection.

Cystectomy with OBS is an extensive surgery, and complications are therefore common. The current results indicate early complications in more than one-third and late complications in more than half of patients. Especially, the late complication rates seem worse compared to other large series. Early complication rates ranging from 12.6 to $33.6 \%$ and late complication rates between 23.8 and $32 \%$ have been reported at long-term follow-up (Studer et al. 2006; Hautmann et al. 1999; Shaaban et al. 2003; Stein et al. 2004; Meyer et al. 2009). However, high rates of 44 and $61 \%$ for early and 48 and $51 \%$ for late complications have also been reported (Jensen et al. 2006; Nieuwenhuijzen et al. 2008). The relatively long average follow-up time of 78.7 months may partially explain our elevated late complication rate. Almost all patients return for follow-up visits at our center where a very explicit and detailed history is noted in regular follow-up visits. This approach may have led to an increased detection of (minor) complications.

A more nuanced view emerges when we study these complications in detail. Of the 69 early complications encountered in 119 patients, only 15 (21.7\%) were major according to the CCS; thus, major early complications seem to be rather sporadic. Of the 95 late complications in 111 patients, 56 (58.9\%) were considered major (CCS III-V). In contrast to early complications, a significant portion of the late complications seemed to be serious. For example, $15.3 \%$ of patients had open surgical repair of a wound herniation (1.5-6.4 \% in other series) (Studer et al. 2006; Hautmann et al. 1999, 2011). Our NUS rate was $9.9 \%$ whereas other large series have yielded stenosis rates ranging from 2.2 to $3.7 \%$ (Studer et al. 2006; Hautmann et al. 1999). This rate is noteworthy because generally a simple buttonhole anastomosis was created, so that urethral stenosis rates would be expected to be similar to other series. These patients underwent re-intervention under (general) anesthesia (urethrotomy, transurethral resection and dilatation).

The late ureteroneovesical stenosis rate in this series was $5.4 \%$. Most patients underwent ureteral reimplantation, and only two had a lifelong single-J stenting. The ureteroneovesical anastomosis was created by a simple refluxing end-to-end anastomosis, which is believed to have the lowest stenosis rates (Roth et al. 1997). An antireflux anastomosis is not considered necessary for three reasons: An OIN is a low-pressure system that cannot provoke active reflux; the afferent ileal limb acts as an anti-reflux protection mechanism; and urine in an OIN is considered to be sterile (Hautmann et al. 2006). Stenosis rates are higher in anti-reflux valve anastomoses $(9 \%)$ 
while refluxing anastomoses stenosis rates are generally reported in no more than 3 \% (Studer et al. 2006; Hautmann et al. 1999; Gakis and Stenzl 2010). Long-term and adequate follow-up could again explain the higher stenosis rate in our series.

Of particular interest are the continence rates. DTC rates are generally excellent in large series; continence is mostly achieved in more than $90 \%$ of patients (both male and female), although definitions of continence may differ (Studer et al. 2006; Hautmann et al. 1999; Litwin et al. 1998; Shaaban et al. 2003; Abol-Enein and Ghoneim 2001). When pragmatically considering G1 and G2 (maximum one pad a day) as being continent, DTC reaches up to $96 \%$ in this series, consisting predominantly of men. At the 3-month interval, $82 \%$ of male patients were continent, and this rate gradually reached a plateau at $95 \%$.

The female population in this study was small; therefore, no strong conclusions can be drawn for this patient group. During the first 6 months, DTC rates matched those of the male population. There seemed, however, to be a more substantial portion of female patients who continued to need a (safety) pad (G2), a number that continued to rise with longer follow-up. The steep rise in incontinence rates (G3) towards the last follow-up can probably be explained by de novo stress incontinence. Two female patients had sling surgery (many years after cystectomy) due to deteriorating stress incontinence.

At the 3 -month interval, only $32 \%$ of male and $53 \%$ of female patients achieved NTC. Generally NTC improves more slowly than DTC (Hautmann et al. 1999). NTC rates in male and female patients (including G1 and G2) were 63 and $73 \%$, respectively, at the 2 -year interval, thereafter reaching a plateau.

We present good DTC rates (Figs. 2a, 3a) for the male patients, which are comparable to other series (Studer et al. 2006; Hautmann et al. 1999; Shaaban et al. 2003; Gakis and Stenzl 2010; Abol-Enein and Ghoneim 2001). Our NTC rate of approximately $60-70 \%$ (Figs. 2b, 3b) appears to be lower than the other series (Studer et al. 2006; Abol-Enein and Ghoneim 2001), but a formal comparison is not possible because the definition of incontinence is pragmatic and subjective, and methods and follow-up times for assessing incontinence vary. In particular, nighttime incontinence has no clear definition in most series and can be influenced by nocturnal voiding, patient motivation and neobladder capacity. Perhaps these factors explain the rather low but probably realistic NTC rates in this report. Unfortunately, we have no accurate data on nightly micturition rates, as frequent nightly micturition could improve nighttime incontinence rates.

As some authors have noted, hypercontinence is not an infrequent problem, especially among female patients,

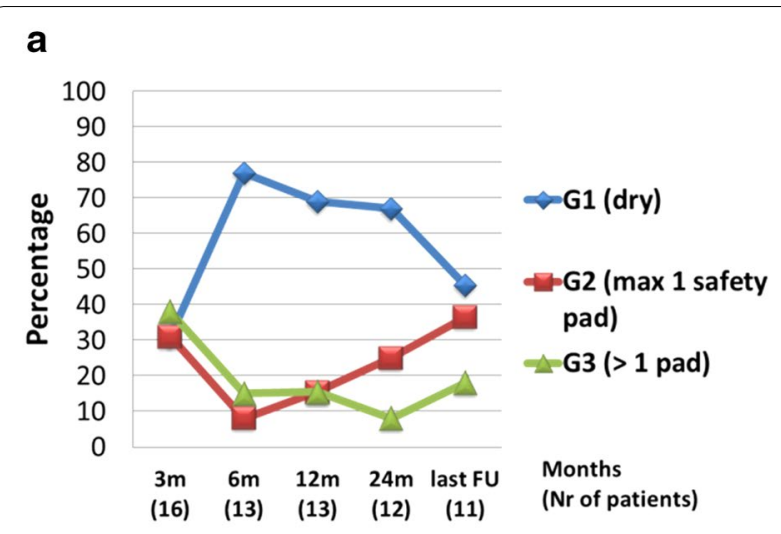

b

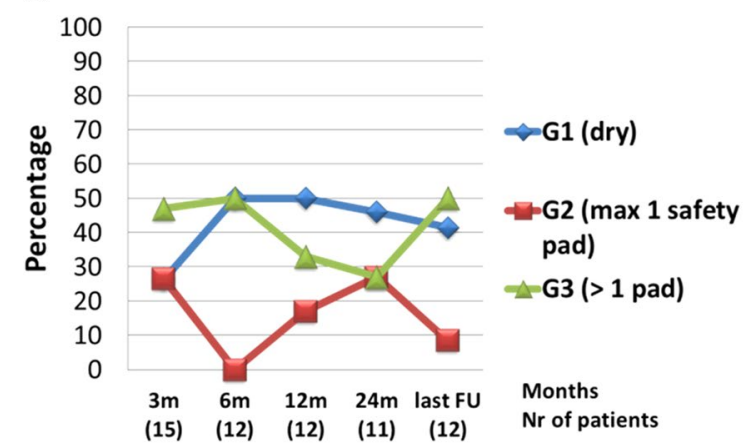

Fig. 3 Female continence. a Daytime female continence. b Nighttime female continence

with rates of 16-33\% (Arai et al. 1999; Lee et al. 2004). This high percentage particularly in women can be due to kinking of the neobladder at the level of bladder neck due to a wider pelvis, absence of posterior support by the uterus, or injury of the autonomous nerves of the urethra. Most hypercontinent men remain able to void spontaneously, while women do not. All patients should be willing to self-catheterize before undergoing surgery. Because of the risk for nightly incontinence and self-catheterization, OBS should be recommended only to highly motivated patients.

This study has some limitations. With the retrospective design, we could not evaluate all patients for all data because of some deaths and missing data. Moreover, we acknowledge complication underreporting in retrospective studies, and complications treated outside our center could have been missed. We used the CCS to standardize complication reporting and differentiate major and minor complications. Although this classification was not originally developed for complications seen later than 90 days after surgery, CCS appears to be reasonably appropriate for reporting long-term complications; however, Hautmann et al. (2011) concluded 
that it seemed less suited for doing so. Nevertheless, there is no specific scoring system dedicated solely to the early/late complications of RC and urinary diversion. Our rather high complication rates could arise from very accurate data gathering that, combined with a long follow-up, possibly has yielded more realistic rates than other series. As Donat (2007) proposed and Shabsigh et al. (2009) demonstrated, meticulously reporting short- and long-term complications gives better information about true incidence and outcome not only in $\mathrm{RC}$ series but also in other uro-oncological procedures.

\section{Conclusion}

We present a retrospective analysis of 119 patients who underwent the Leuven $\mathrm{N}$-pouch with long-term followup. Complication rates were relatively high, reflecting a strict and meticulous follow-up scheme. Good DTC rates for male patients were achieved, but NTC rates were less than ideal. High complication and nighttime incontinence rates strongly support reserving OBS only for thoroughly selected patients who can self-catheterize .

\begin{abstract}
Abbreviations
RC: radical cystectomy; OIN: orthotopic ileal neobladder; IC: ileal conduit; OBS: orthotopic bladder substitution; CCS: Clavien-Dindo classification score; UCLA: University of California, Los Angeles; G: group; DTC: daytime continence; NTC: nighttime continence; UTI: urinary tract infection; NUS: neovesicourethral stenosis.

\section{Authors' contributions}

TDS: Data collection, data management, data analysis, manuscript writing, manuscript editing. MAk: Data management, data analysis, manuscript writing, manuscript editing. MAI, WE, BVC: Data collection, manuscript editing. DDR, HVP: Data collection, data management, manuscript editing, critical revision of manuscript. HG, LM, UM: Data collection, data management, data analysis. FVDA, SJ: Project development, data collection, data management, manuscript editing, critical revision of manuscript. All authors read and approved the final manuscript.
\end{abstract}

\section{Author details}

${ }^{1}$ Department of Urology, University Hospitals Leuven, Herestraat 49, 3000 Leuven, Belgium. ${ }^{2}$ Department of Urology, School of Medicine, Selcuk University, Konya, Turkey. ${ }^{3}$ Department of Urology, Ziekenhuis Oost-Limburg, Genk, Belgium.

\section{Acknowledgements}

Thomas De Sutter and Murat Akand are co-first authors of the article. Frank Van Der Aa and Steven Joniau are the joint last authors. Murat Akand is supported by a clinical scholarship from the European Urologic Scholarship Program (EUSP). Steven Joniau is supported by Klinisch Onderzoeksfonds (KOF) UZ Leuven.

\section{Competing interests}

The authors declare that they have no competing interests.

Ethics approval and consent to participate

The study was approved by the Local Ethics Committee with a waiver of informed consent.

Received: 7 March 2016 Accepted: 5 May 2016

Published online: 17 May 2016

\section{References}

Abol-Enein H, Ghoneim MA (2001) Functional results of orthotopic ileal neobladder with serous-lined extramural ureteral reimplantation: experience with 450 patients. J Urol 165:1427-1432

Arai Y, Okubo K, Konami T, Kin S, Kanba T, Okabe T, Hamaguchi A, Okada Y (1999) Voiding function of orthotopic ileal neobladder in women. Urology 54:44-49

Dindo D, Demartines N, Clavien PA (2004) Classification of surgical complications: a new proposal with evaluation in a cohort of 6336 patients and results of a survey. Ann Surg 240:205-213

Donat SM (2007) Standards for surgical complication reporting in urologic oncology: time for a change. Urology 69:221-225

Gakis G, Stenzl A (2010) Ileal neobladder and its variants. Eur Urol Suppl 9:745-753

Gore JL, Litwin MS, Urologic Diseases in America Project (2009) Quality of care in bladder cancer: trends in urinary diversion following radical cystectomy. World J Urol 27:45-50

Hautmann RE (2003) Urinary diversion: ileal conduit to neobladder. J Urol 169:834-842

Hautmann RE, Egghart G, Frohneberg D, Miller K (1988) The ileal neobladder. J Urol 139:39-42

Hautmann RE, de Petriconi R, Gottfried HW, Kleinscmidt K, Mattes R, Paiss T (1999) The ileal neobladder: complications and functional results in 363 patients after 11 years of follow-up. J Urol 161:422-427

Hautmann RE, Volkmer BG, Schumacher MC, Gschwend JE, Studer UE (2006) Long-term results of standard procedures in urology: the ileal neobladder. World J Urol 24:305-314

Hautmann RE, de Petriconi RC, Volkmer BG (2011) 25 years of experience with 1,000 neobladders: long-term complications. J Urol 185:2207-2212

Hautmann RE, Abol-Enein H, Davidsson T, Gudjonsson S, Hautmann SH, Holm HV, Lee CT, Liedberg F, Madersbacher S, Manoharan M, Mansson W, Mills RD, Penson DF, Skinner EC, Stein R, Studer UE, Thueroff JW, Turner WH, Volkmer BG, Xu A, International Consultation on Urologic Disease-European Association of Urology Consultation on Bladder Cancer 2012 (2013) ICUD-EAU International Consultation on Bladder Cancer 2012: urinary diversion. Eur Urol 63:67-80

Hinman F Jr (1998) Selection of intestinal segments for bladder substitution: physical and physiological characteristics. J Urol 139:519-523

Jahnson S, Holmang S, Damm O et al (2008) Nationellt kvalitetsregister för blåscancer. Rapport för diagnosår. Socialstyrelsen, Stockholm

Jensen JB, Lundbeck F, Jensen KM (2006) Complications and neobladder function of the Hautmann orthotopic ileal neobladder. BJU Int 98:1289-1294

Joniau S, Benijts J, Van Kampen M, De Waele M, Ooms J, Van Cleynenbreugel B, Van Poppel $\mathrm{H}$ (2005) Clinical experience with the $\mathrm{N}$-shaped ileal neobladder: assessment of complications, voiding patterns, and quality of life in our series of 58 patients. Eur Urol 47:666-672

Lee CT, Hafez KS, Sheffield JH, Joshi DP, Montie JE (2004) Orthotopic bladder substitution in women: non-traditional applications. J Urol 171:1585-1588

Litwin MS, Hays RD, Fink A, Ganz PA, Leake B, Brook RH (1998) The UCLA Prostate Cancer Index: development, reliability, and validity of a healthrelated quality of life measure. Med Care 36:1002-1012

Meyer JP, Blick C, Arumainayagam N, Hurley K, Gillatt D, Persad R, Fawcett D (2009) A three-centre experience of orthotopic neobladder reconstruction after radical cystectomy: revisiting the initial experience, and results in 104 patients. BJU Int 103:680-683

Nam JK, Kim TN, Park SW, Lee SD, Chung MK (2013) The Studer orthotopic neobladder: long-term (more than 10 years) functional outcomes, urodynamic features, and complications. Yonsei Med J 54:690-695

Nieuwenhuijzen JA, de Vries RR, Bex A, van der Poel HG, Meinhardt W, Antonini N, Horenblas S (2008) Urinary diversions after cystectomy: the association of clinical factors, complications and functional results of four different diversions. Eur Urol 53:834-842

Roth S, van Ahlen H, Semjonow A, Oberpenning F, Hertle L (1997) Does the success of ureterointestinal implantation in orthotopic bladder substitution depend more on surgeon level of experience or choice of technique? J Urol 157:56-60

Shaaban AA, Mosbah A, El-Bahnasawy MS, Madbouly K, Ghoneim MA (2003) The urethral Kock pouch: long-term functional and oncological results in men. BJU Int 92:429-435 
Shabsigh A, Korets R, Vora KC, Brooks CM, Cronin AM, Savage C, Raj G, Bochner BH, Dalbagni G, Herr HW, Donat SM (2009) Defining early morbidity of radical cystectomy for patients with bladder cancer using a standard reporting methodology. Eur Urol 55:164-174

Singh V, Mandal S, Patil S, Sinha RJ, Gupta DK, Sankhwar SN (2014) Urodynamic and continence assessment of orthotopic neobladder reconstruction following radical cystectomy in bladder cancer; a prospective, blinded North Indian tertiary care experience. South Asian J Cancer 3:223-226

Stein JP, Dunn MD, Quek ML, Miranda G, Skinner DG (2004) The orthotopic T pouch ileal neobladder: experience with 209 patients. J Urol 172:584-587

Studer UE, Ackermann D, Casanova GA, Zingg EJ (1989) Three years' experience with an ileal low pressure bladder substitute. Br J Urol 63:43-52
Studer UE, Burkhard FC, Schumacher M, Kessler TM, Thoemy H, Fleischmann A, Thalmann GN (2006) Twenty years experience with an ileal orthotopic low pressure bladder substitute-lessons to be learned. J Urol 176:161-166

Witjes JA, Comperat E, Cowan NC, De Santis M, Gakis G, Lebret T, Ribal MJ, Van der Heijden AG, Sherif A, European Association of Urology (2014) EAU guidelines on muscle-invasive and metastatic bladder cancer. Eur Urol 65:778-792

Yossepowitch O, Dalbagni G, Golijanin D, Donat SM, Bochner BH, Herr HW, Fair WR, Russo P (2003) Orthotopic urinary diversion after cystectomy for bladder cancer: implications for cancer control and patterns of disease recurrence. J Urol 169:177-181

\section{Submit your manuscript to a SpringerOpen ${ }^{\circ}$ journal and benefit from:}

- Convenient online submission

\section{- Rigorous peer review}

Immediate publication on acceptance

- Open access: articles freely available online

- High visibility within the field

- Retaining the copyright to your article 